\title{
DEVELOPMENT OF AN INSOLUBLE SALT SIMULANT TO SUPPORT ENHANCED CHEMICAL CLEANING TESTS
}

Russell E. Eibling

April 2008

Process Science \& Engineering Section Savannah River National Laboratory Aiken, SC 29808 


\section{DISCLAIMER}

This report was prepared by Washington Savannah River Company (WSRC) for the United States Department of Energy under Contract No. DE-AC09-96SR18500 and is an account of work performed under that contract. Neither the United States Department of Energy, nor WSRC, nor any of their employees makes any warranty, expressed or implied, or assumes any legal liability or responsibility for the accuracy, completeness, or usefulness, of any information, apparatus, or product or process disclosed herein or represents that its use will not infringe privately owned rights. Reference herein to any specific commercial product, process, or service by trademark, name, manufacturer or otherwise does not necessarily constitute or imply endorsement, recommendation, or favoring of same by WSRC or by the United States Government or any agency thereof. The views and opinions of the authors expressed herein do not necessarily state or reflect those of the United States Government or any agency thereof.

\section{Printed in the United States of America \\ Prepared For U.S. Department of Energy}




\section{Retention:}

\section{DEVELOPMENT OF AN INSOLUBLE SALT SIMULANT TO SUPPORT ENHANCED CHEMICAL CLEANING TESTS}

Russell E. Eibling

April 2008

Process Science \& Engineering Section Savannah River National Laboratory Aiken, SC 29808 
WSRC-STI-2008-00079

Revision 0

\section{REVIEWS AND APPROVALS}

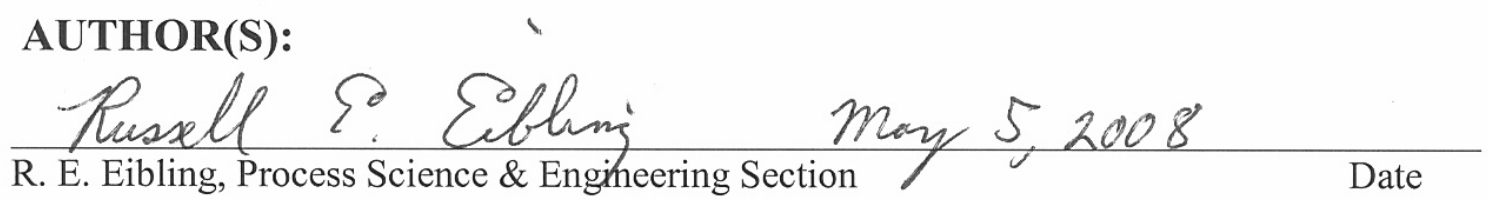

TECHNICAL REVIEWERS:

APPROVERS 


\section{EXECUTIVE SUMMARY}

The closure process for high level waste tanks at the Savannah River Site will require dissolution of the crystallized salts that are currently stored in many of the tanks. The insoluble residue from salt dissolution is planned to be removed by an Enhanced Chemical Cleaning (ECC) process. Development of a chemical cleaning process requires an insoluble salt simulant to support evaluation tests of different cleaning methods. The Process Science and Engineering section of SRNL has been asked to develop an insoluble salt simulant for use in testing potential ECC processes (HLE-TTR-2007-017).

An insoluble salt simulant has been developed based upon the residues from salt dissolution of saltcake core samples from Tank 28F. The simulant was developed for use in testing SRS waste tank chemical cleaning methods. Based on the results of the simulant development process, the following observations were developed:

- A composition based on the presence of 10.35 grams oxalate and 4.68 grams carbonate per 100 grams solids produces a sufficiently insoluble solids simulant.

- Aluminum observed in the solids remaining from actual waste salt dissolution tests is probably precipitated from sodium aluminate due to the low hydroxide content of the saltcake.

- In-situ generation of aluminum hydroxide (by use of aluminate as the Al source) appears to trap additional salts in the simulant in a manner similar to that expected for actual waste samples.

- Alternative compositions are possible with higher oxalate levels and lower carbonate levels. The maximum oxalate level is limited by the required $\mathrm{Na}$ content of the insoluble solids.

- Periodic mixing may help to limit crystal growth in this type of salt simulant.

- Long term storage of an insoluble salt simulant is likely to produce a material that can not be easily removed from the storage container. Production of a relatively fresh simulant is best if pumping the simulant is necessary for testing purposes.

The insoluble salt simulant described in this report represents the initial attempt to represent the material which may be encountered during final waste removal and tank cleaning. The final selected simulant was produced by heating and evaporation of a salt slurry sample to remove excess water and promote formation and precipitation of solids with solubility characteristics which are consistent with actual tank insoluble salt samples. The exact anion composition of the final product solids is not explicitly known since the chemical components in the final product are distributed between the solid and liquid phases. By combining the liquid phase analyses and total solids analysis with mass balance requirements a calculated composition of assumed simple compounds was obtained and is shown in Table $0-1$. 
WSRC-STI-2008-00079

Revision 0

Table 0-1 Calculated Composition of the Insoluble Salt Simulant Solids

\begin{tabular}{|c|c|c|}
\hline Compound & Formula & $\begin{array}{c}\text { Wt \% } \\
\text { Basis }\end{array}$ \\
\hline Aluminum Hydroxide & $\mathrm{Al}(\mathrm{OH})_{3}$ & 37.0 \\
\hline Calcium Carbonate & $\mathrm{CaCO}$ & 0.9 \\
\hline Ferric Hydroxide & $\mathrm{Fe}(\mathrm{OH})_{3}$ & 4.9 \\
\hline $\begin{array}{c}\text { Sodium Fluoride } \\
\text { Phosphate }\end{array}$ & $\mathrm{Na}_{3} \mathrm{~F}\left(\mathrm{PO}_{4}\right)_{2} .19 \mathrm{H}_{2} \mathrm{O}$ & 3.6 \\
\hline Silica & $\mathrm{SiO}_{2}$ & 4.7 \\
\hline Sodium Nitrate & $\mathrm{NaNO}_{3}$ & 2.4 \\
\hline Sodium Oxalate & $\mathrm{Na}_{2} \mathrm{C}_{2} \mathrm{O}_{4}$ & 46.5 \\
\hline
\end{tabular}

Additional improvements to and further characterization of the insoluble salt simulant are possible. During the development of these simulants it was recognized that:

- Additional waste characterization on the residues from salt dissolution tests with actual waste samples to determine the amount of species such as carbonate, oxalate and aluminosilicate would allow fewer assumptions to be made in constructing an insoluble salt simulant.

- The tank history will impact the amount and type of insoluble solids that exist in the salt dissolution solids. Varying the method of simulant production (elevated temperature processing time, degree of evaporation, amount of mixing (shear) during preparation, etc.) should be tested. 


\section{TABLE OF CONTENTS}

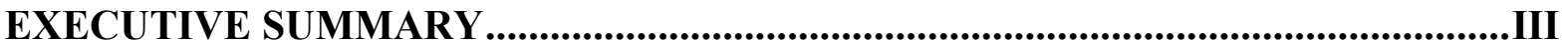

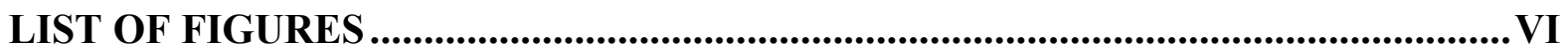

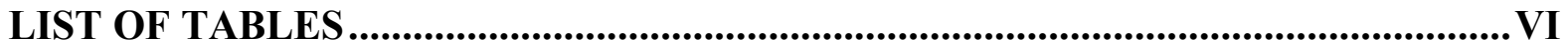

LIST OF ACRONYMS ................................................................................ VII

1.0 INTRODUCTION AND BACKGROUND ............................................................ 1

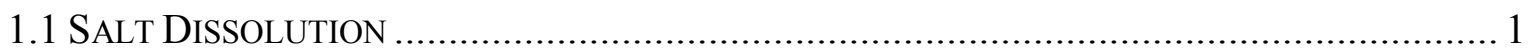

1.2 TANK 28 F InSOLUBLE SALT ...................................................................... 1

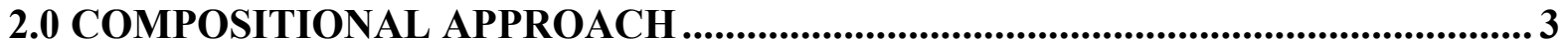

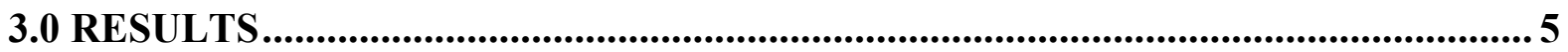

3.1 SimUlant DeVELOPMENT.............................................................................. 5

3.2 InSOLUBLE SALt Simulant COMPOSITION AND PROPERTIES .................................. 7

3.3 ECC Insoluble Salt Simulant Produced for Enhanced Chemical Cleaning

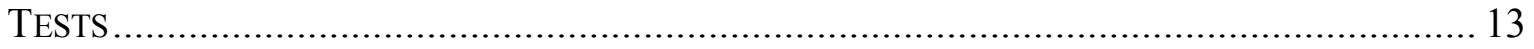

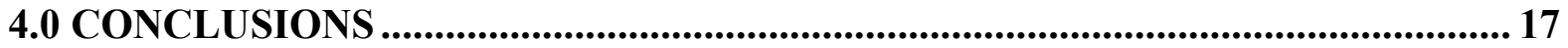

5.0 RECOMMENDATIONS/PATH FORWARD ................................................ 19

6.0 REFERENCES ............................................................................................. 21

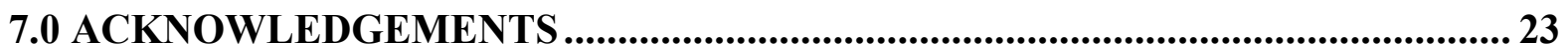

APPENDIX A. INSOLUBLE SALT SIMULANT RECIPE WITHOUT RCRA

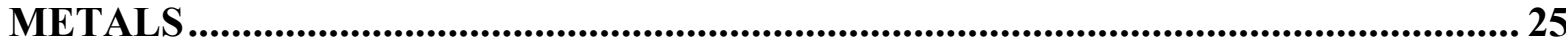

APPENDIX B. INSOLUBLE SALT SIMULANT RECIPE WITH RCRA METALS . 29 


\section{LIST OF FIGURES}

Figure 3-1 Vane Measurement of Settled Solids Shear Strength after 90 Hours Settling..... 11

Figure 3-2 Crystals in the NoRCRA Insoluble Salt Simulant......................................... 12

Figure 3-3 Vane Measurement after 29 days .......................................................... 12

Figure 3-4 Sodium Carbonate Decahydrate Crystals in Insoluble Salt Simulant ................ 13

\section{LIST OF TABLES}

Table 0-1 Calculated Composition of the Insoluble Salt Simulant Solids.......................... iv

Table 1-1 Tank 28F Saltcake Residual Insoluble Solids Analysis.................................... 2

Table 2-1 Initial Compositional Basis for the Insoluble Salt Simulant ............................. 3

Table 3-1 Tested Insoluble Salt Basis Formulations ........................................................ 5

Table 3-2 Tank 28 Core Leachate Simulant ................................................................ 6

Table 3-3 Dissolution Test Results for Candidate Insoluble Salt Simulants ....................... 7

Table 3-4 Insoluble Salt Simulant Weight Percent Solids, Density and pH Results ............ 8

Table 3-5 ICPES Results for the Insoluble Salt Simulants Centrifuged Dried Solids ........... 9

Table 3-6 Simulants Compared to Target Values ................................................. 10

Table 3-7 Cone and Plate Rheology Program.......................................................... 11

Table 3-8 ECC Insoluble Salt Simulant Physical Properties ........................................... 13

Table 3-9 Dissolution Test Results for the ECC Insoluble Salt Simulant .......................... 14

Table 3-10 Elemental Analysis Results for the ECC Insoluble Salt Simulant ................... 14

Table 3-11 ECC Insoluble Salt Simulant Supernate Composition.................................. 15

Table 3-12 Calculated Composition of the ECC Insoluble Salt Simulant Solids ................ 15 


\section{LIST OF ACRONYMS}

$\begin{array}{ll}\text { AA } & \text { Atomic Absorption Spectrophotometer } \\ \text { ACTL } & \text { Aiken County Technology Laboratory } \\ \text { cP } & \text { Centipoise } \\ \text { ECC } & \text { Enhanced Chemical Cleaning } \\ \text { IC } & \text { Ion Chromatography } \\ \text { ICPES } & \text { Inductively Coupled Plasma Emission Spectrophotometer } \\ \text { ICPMS } & \text { Inductively Coupled Plasma Mass Spectrometry } \\ \text { IS } & \text { Insoluble Solids } \\ \text { L } & \text { Liters } \\ \text { LWO } & \text { Liquid Waste Organization } \\ \text { M } & \text { Moles/Liter } \\ \text { mL } & \text { Milliliter } \\ \text { mPa.sec } & \text { millipascal.seconds } \\ \text { NIST } & \text { National Institute of Standards and Technology } \\ \text { Pa } & \text { Pascals } \\ \text { RCRA } & \text { Resource Conservation and Recovery Act } \\ \text { SRNL } & \text { Savannah River National Laboratory } \\ \text { SSYS } & \text { Settled Solids Yield Stress }\end{array}$


WSRC-STI-2008-00079

Revision 0

This page intentionally left blank. 


\subsection{INTRODUCTION AND BACKGROUND}

The Liquid Waste Organization (LWO), Technology Development group is developing the Enhanced Chemical Cleaning (ECC) process to aid in final waste removal from high level waste tanks prior to closure. The ECC process is applied to a waste tank after bulk waste removal and mechanical cleaning have been completed. Development of the ECC process requires the use of various waste simulants for testing the process. The Process Science and Engineering section of SRNL has been asked to develop an insoluble salt simulant for use in testing potential ECC processes (HLE-TTR-2007-017).

\subsection{Salt Dissolution}

High level waste at the Savannah River Site is stored in large steel tanks as either insoluble sludge made up of transition metal hydroxides/oxides or as a saltcake composed of crystallized salts plus associated free liquid. The saltcake is produced by concentrating the soluble salts in the free liquid through evaporation. Closure of the waste tanks containing saltcake begins by removal of the existing free liquid within the tank. Bulk waste removal of the remaining saltcake utilizes dissolution of the crystallized salts with corrosion-inhibited water. Salt dissolution begins by dissolving the most soluble species and progresses toward the least soluble species as a function of the volume of water used and the composition of the saltcake. The residual solids remaining after salt dissolution are the target material for the ECC process and are composed of the least soluble salts, entrained sludge solids and solids precipitated during salt dissolution.

\subsection{Tank 28 F Insoluble Salt}

Salt dissolution has been studied using core samples from various tanks containing saltcake. The insoluble salt simulant was derived from the compositional information obtained during studies on core samples from Tank 28F. Tank 28F was core sampled February 2006 and the sample characterization results were documented in WSRC-STI-2006-00151. ${ }^{1}$ A composite of the core samples was tested for salt dissolution by adding one part of saltcake to four parts of water. The undissolved solids from the dissolution test were dissolved with hydrochloric acid/nitric acid mixture (aqua regia) and the liquid analyzed by inductively coupled plasma emission spectrophotometer (ICPES), inductively coupled plasma mass spectrometry (ICPMS) and atomic absorption spectrophotometer (AA). Additional information about the more soluble species is available from the ICPES and ion chromatography (IC) analysis of the dissolution solutions. The starting analytical basis for the insoluble salt simulant is shown in Table 1-1. 
WSRC-STI-2008-00079

Revision 0

Table 1-1 Tank 28F Saltcake Residual Insoluble Solids Analysis

\begin{tabular}{|c|c|}
\hline Species & grams/100 gram solids \\
\hline $\mathrm{Ag}$ & 0.0044 \\
\hline $\mathrm{Al}$ & 5.62 \\
\hline $\mathrm{Ba}$ & 0.034 \\
\hline $\mathrm{Ca}$ & 0.144 \\
\hline $\mathrm{Cd}$ & 0.0014 \\
\hline $\mathrm{Cr}$ & 0.734 \\
\hline $\mathrm{Fe}$ & 0.961 \\
\hline $\mathrm{K}$ & 0.04 \\
\hline $\mathrm{Mo}$ & $<0.308$ \\
\hline $\mathrm{Na}$ & 15.80 \\
\hline $\mathrm{P}$ & $<0.356$ \\
\hline $\mathrm{Pb}$ & 0.0065 \\
\hline $\mathrm{Pd}$ & 0.023 \\
\hline $\mathrm{S}$ & 0.535 \\
\hline $\mathrm{Si}$ & $<0.714$ \\
\hline $\mathrm{U}$ & 0.379 \\
\hline $\mathrm{W}$ & 0.029 \\
\hline
\end{tabular}




\subsection{COMPOSITIONAL APPROACH}

Development of an insoluble salt simulant requires a combination of the measured species with appropriate counter ions to generate compounds of limited or no solubility. The information available for the expected insoluble salt solids is limited in scope for the purpose of formulating a simulant. Table 1-1 provides information for the major cation-forming elemental species but does not provide sufficient information to define all of the anion species in the solids. The compositional approach to formulating an insoluble simulant was based on combining the known species with appropriate limited solubility anions expected to be present in SRS salt waste while maintaining the appropriate charge balance as defined by the $\mathrm{Na}$ content. These appropriate anions should not invalidate the existing analytical information listed in Table 1-1.

The sample preparation method (aqua regia dissolution) used on the residual solids from the Tank $28 \mathrm{~F}$ core dissolution prevents the analysis of most of the expected anions in SRS salt waste. The application of the hot, oxidizing acid eliminates hydroxides, carbonates, organic anions (oxalate, formate, acetate, etc.) and nitrite. Additionally, the use of nitric acid prevents the quantitative analysis of nitrate in the residue. The $\mathrm{Cr}, \mathrm{P}, \mathrm{W}$ and $\mathrm{S}$ that are reported in Table 1-1 can be considered to represent chromate, phosphate, tungstate, and sulfate anions. Based on data from x-ray diffraction analysis, sodium nitrate is also present in the residual solids despite the expected high solubility for the nitrate salt. Therefore, some level of nitrate will also be included in the simulant. Sequential and flow-through dissolution studies on core samples at SRS and Hanford have previously shown that the last portions of the salt to dissolve are composed of sulfate, carbonate and oxalate species. ${ }^{1,2,3}$ The amount of sulfate in the residual insoluble solids is already defined by the amount listed in Table 1-1.

The tested insoluble salt compositions were based on various levels of added carbonate and oxalate as limited by the amount of sodium measured in the Tank $28 \mathrm{~F}$ salt dissolution residue. The charge balance was achieved by addition of nitrate to balance the remaining sodium. Fluoride was also added to the simulant to allow the production of double salts such as a sodium fluorophosphates. The initial compositional basis for the insoluble salt simulant is shown in Table 2-1.

Table 2-1 Initial Compositional Basis for the Insoluble Salt Simulant

\begin{tabular}{|c|c|}
\hline Species & grams/100 gram solids \\
\hline $\mathrm{Al}$ & 5.62 \\
\hline $\mathrm{Ca}$ & 0.144 \\
\hline $\mathrm{Cr}$ & 0.734 \\
\hline $\mathrm{Fe}$ & 0.961 \\
\hline $\mathrm{K}$ & 0.04 \\
\hline $\mathrm{Mo}$ & 0.308 \\
\hline $\mathrm{Na}$ & 15.80 \\
\hline $\mathrm{Pb}$ & 0.0065 \\
\hline $\mathrm{Si}$ & 0.714 \\
\hline
\end{tabular}




\begin{tabular}{|c|c|}
\hline Species & grams/100 gram solids \\
\hline $\mathrm{W}$ & 0.029 \\
\hline $\mathrm{CO}_{3}^{-2}$ & 1.870 \\
\hline $\mathrm{C}_{2} \mathrm{O}_{4}^{-2}$ & 0.207 \\
\hline $\mathrm{F}^{-}$ & 0.068 \\
\hline $\mathrm{NO}_{3}^{-}$ & 28.710 \\
\hline $\mathrm{PO}_{4}^{-3}$ & 1.092 \\
\hline $\mathrm{SO}_{4}^{-2}$ & 1.603 \\
\hline
\end{tabular}

The species in Table 1-1 that were listed as less than values were placed in the initial simulant basis at that specific value. Silicon, for example, could actually be higher than the less than value since aqua regia dissolution is not very effective at dissolving silica or some insoluble silicates. The initial concentrations for fluoride, oxalate and carbonate were derived from the information on the dissolved portion of the Tank $28 \mathrm{~F}$ core. ${ }^{1}$ The initial high concentration of nitrate was obtained by calculating the charge balance between all of the anions except nitrate and the sum of the $\mathrm{Na}$ and $\mathrm{K}$ concentrations. The remaining portion of the unassigned moles of positive charge was assigned to nitrate to generate the nitrate concentration reported above.

The conversion of the information in Table 2-1 to a simulant recipe consisted of the following steps.

A. First convert the amount of each species to moles/100 grams of solids basis.

B. Identify the expected compounds to be generated and the source chemicals to be used in producing those target compounds.

C. Convert the moles per 100 grams solids to moles /mole Na by ratioing each species to Na.

D. Determine the target $\mathrm{Na}$ moles/liter concentration for the initial slurry preparation and use this value to scale all of the remaining reagents to the target Na concentration.

E. Determine the order of addition to prevent decomposition of desired target species. For example, precipitation of Ferric species by hydroxide must be completed before any addition of carbonate to prevent the acidic ferric ion from generating $\mathrm{CO}_{2}$ from the carbonate.

F. Complete and test the recipe by examining the solubility of the final centrifuged solids in water and in a salt solution.

The final step in the compositional approach was to add some processing that mimics the way the original saltcake was produced in the tank farm. This was accomplished by starting with a slurry which is concentrated by evaporation to increase the amount of precipitated/crystallized solids. The additional thermal processing allows species that can react such as silicate and aluminate to generate less soluble aluminosilicates. 


\subsection{RESULTS}

\subsection{Simulant Development}

Five different compositions were tested in developing the insoluble salt simulant. Four of the tested simulants varied the carbonate and oxalate levels and added aluminum as two different starting materials. The fifth tested simulant repeated the composition of the fourth simulant but did not include any of the RCRA metals. The primary differences between the tested compositions are shown in where the total added masses of the primary anions and aluminum per 100 grams of solids (as distinguished from the amounts of these anions in the final solid product) are provided.

Table 3-1 where the total added masses of the primary anions and aluminum per 100 grams of solids (as distinguished from the amounts of these anions in the final solid product) are provided.

Table 3-1 Tested Insoluble Salt Basis Formulations

\begin{tabular}{|c|c|c|c|c|c|}
\hline Anions & $\begin{array}{c}\text { 4X } \\
\text { Solids }{ }^{\mathrm{a}}, \\
\text { g/100 g } \\
\text { Solids } \\
\end{array}$ & $\begin{array}{c}\text { 7X Solids } \\
\text { g/100 } \\
\text { g } \\
\text { Solids }\end{array}$ & $\begin{array}{c}\text { Bicarb }^{\mathbf{b}}, \\
\text { g/100 g } \\
\text { Solids }\end{array}$ & $\begin{array}{c}\text { Ox-7X' } \\
\text { g/100 g } \\
\text { Solids }\end{array}$ & $\begin{array}{c}\text { NoRCRA- } \\
\text { 50X' } \\
\text { g/100 g } \\
\text { Solids } \\
\end{array}$ \\
\hline Oxalate & 0.83 & 1.45 & 1.45 & $10.35^{\mathrm{d}}$ & $10.35^{\mathrm{d}}$ \\
\hline Carbonate & 7.48 & 13.09 & $13.09^{\mathrm{e}}$ & $4.68^{\mathrm{e}}$ & $4.68^{\mathrm{e}}$ \\
\hline Nitrate & 16.24 & 3.77 & 4.38 & 8.62 & 10.37 \\
\hline Al Source & $\mathrm{Al}(\mathrm{OH})_{3}$ & $\mathrm{Al}(\mathrm{OH})_{3}$ & $\mathrm{NaAlO}_{2}$ & $\mathrm{NaAlO}_{2}$ & $\mathrm{NaAlO}_{2}$ \\
\hline
\end{tabular}

The aluminum measured in the insoluble portion of the actual saltcake core samples was initially present in the saltcake as sodium aluminate crystals. Dissolution of sodium aluminate crystals without sufficient hydroxide anion available to maintain aluminum solubility will produce a fresh precipitate of aluminum hydroxide. The first two experiments added the aluminum as aluminum hydroxide. The low level of sodium hydroxide added to these tests would not have allowed much of the aluminum hydroxide to dissolve. Adding aluminum in this manner would limit the interaction that would probably be desirable between aluminum and other waste species. Freshly precipitated aluminum hydroxide can be gelatinous and can provide a means of trapping soluble species within the insoluble solids phase. Therefore, the later experiments added aluminum as sodium aluminum oxide, the anhydrous form of sodium aluminate. The soluble aluminate was then converted after dissolution to aluminum hydroxide by reaction with the $\mathrm{H}^{+}$from bicarbonate or oxalic acid.

The amount of carbonate and oxalate in the insoluble salt solids was not defined by the analytical methods used on the Tank $28 \mathrm{~F}$ core analysis. The only limit on the amount of carbonate or oxalate in a test mixture is the requirement for $\mathrm{Na}$ to charge balance the compounds. The initial test mixtures added carbonate and oxalate as the sodium salt but later mixtures added the compounds as sodium bicarbonate and oxalic acid to aid in precipitating the sodium aluminate. 
The solubility of the test insoluble salt simulants was evaluated by determining the leach resistance of the test mixture solids versus distilled water and versus a 2.25 molar Na salt solution. The 2.25 molar $\mathrm{Na}$ salt solution represents the presumably saturated leachate that was in contact with the insoluble salt solids from the Tank $28 \mathrm{~F}$ core sample. ${ }^{1}$ A leachate simulant was prepared based on the composition listed in Table 3-2 which was obtained from reference 1.

Table 3-2 Tank 28 Core Leachate Simulant

\begin{tabular}{|c|c|}
\hline Species & Moles/Liter \\
\hline Sodium & 2.25 \\
\hline Nitrite & 0.069 \\
\hline Nitrate & 1.75 \\
\hline Hydroxide & 0.06 \\
\hline Chloride & 0.0006 \\
\hline Sulfate & 0.08 \\
\hline Fluoride & 0.002 \\
\hline Carbonate & 0.008 \\
\hline Aluminate & 0.20 \\
\hline Oxalate & 0.003 \\
\hline Phosphate & 0.004 \\
\hline Potassium & 0.005 \\
\hline $\begin{array}{c}\text { Density, } \\
\text { g/mL }\end{array}$ & 1.12 \\
\hline
\end{tabular}

The density reported in the table is the measured density for the core Leachate simulant. Initially the simulant was free of insoluble solids. However, after about two weeks white solids were observed in the Leachate simulant. Analysis of the supernate showed that aluminum had eventually precipitated due to the low level of hydroxide added to the simulant. The actual Tank 28 core dissolution also showed evidence of aluminum precipitation. Therefore the Leachate simulant was used to test the solubility of the insoluble solids in the test simulants.

The solubility of the insoluble salt simulants was tested by applying the dissolution method used for the analysis of the Tank $28 \mathrm{~F}$ core samples. The solids from a test batch of the insoluble salt simulant were recovered by centrifuging the simulant at $3300 \mathrm{rpm}$ for 15 minutes using an IEC Centra GP8 centrifuge. The supernate was decanted from the solids. The solids were not washed since washing would eliminate many of the low solubility salts that should be present in the insoluble salt simulant. Ten grams of the solids were added to a $250 \mathrm{~mL}$ polypropylene bottle and then 40 grams of either deionized water or core leachate simulant were added. The bottles were vigorously mixed for thirty seconds and then placed on an Innova 2300 orbital platform shaker and mixed at $120 \mathrm{rpm}$ for 24 hours. The insoluble solids were recovered from dissolution slurries by again centrifuging at $3300 \mathrm{rpm}$ for 15 minutes. The dissolution supernate was decanted and submitted for analysis by IC and ICPES and the remaining solids were weighed. The solids were then submitted for dissolution and analysis by ICPES.

Five different simulant formulations were tested as shown in Table 3-1. The results of the dissolution tests on the test formulations are shown in Table 3-3. The first two formulations were based on adding carbonate and oxalate at four times and seven times the starting values given in Table 2-1. The initial 
factor of four times was based on the logic that if the supernate had a concentration for a lower solubility salt in solution, then, the solid phase should have a higher concentration than the supernate. The seven times factor was chosen because that is nearly the maximum amount of carbonate that could be present in the solids for the given sodium concentration and still have some nitrate required for charge balancing. The third test formulation was also at $7 \mathrm{X}$ the carbonate and oxalate levels but also changed the addition of aluminum to generate fresh aluminum precipitant. A comparison of the dissolution results for the $4 \mathrm{X}$ and $7 \mathrm{X}$ test formulations reveals that only a small increase in insoluble salts (as indicated by decreased weight percent dissolution) occurred when the amount of carbonate and oxalate nearly doubled. This suggests that most of the increased insolubility was due to oxalate since the net mass increase in oxalate was small. The third formulation tested changing the aluminum source material to sodium aluminate and used sodium bicarbonate as the carbonate source and as the $\mathrm{H}^{+}$source for precipitating the aluminum. This change allows for the possible trapping of soluble species within the precipitated aluminum hydroxide structure and also makes aluminum ion available for reaction with silicon to generate an insoluble aluminosilicate species. A more significant change in solubility was produced with the aluminate-bicarbonate change but sill not as much as seemed desirable (i.e. too much still soluble in the core leachate dissolution test).

Table 3-3 Dissolution Test Results for Candidate Insoluble Salt Simulants

\begin{tabular}{|c|c|c|c|c|c|}
\hline $\begin{array}{c}\text { Dissolution } \\
\text { Tests }\end{array}$ & $\begin{array}{c}\text { 4X Solids } \\
\text { wt. \% } \\
\text { Dissolved }\end{array}$ & $\begin{array}{c}\text { 7X Solids } \\
\text { wt. \% } \\
\text { Dissolved }\end{array}$ & $\begin{array}{c}\text { Bicarb } \\
\text { wt. \% } \\
\text { Dissolved }\end{array}$ & $\begin{array}{c}\text { Ox-7X } \\
\text { wt. \% } \\
\text { Dissolved }\end{array}$ & $\begin{array}{c}\text { NoRCRA- } \\
\text { 50X } \\
\text { wt. \% } \\
\text { Dissolved }\end{array}$ \\
\hline $\begin{array}{c}\text { Deionized } \\
\text { Water } \\
\text { Tank 28 Core } \\
\text { Leachate }\end{array}$ & $54.1 \pm 0.3$ & $52.6 \pm 0.3$ & $44.2 \pm 0.2$ & $22.8 \pm 1.6$ & $22.1 \pm 4.2$ \\
\hline
\end{tabular}

The final two test formulations combine the use of sodium aluminate with much higher oxalate addition level and a lower carbonate level. The oxalate level is 50 times the initial starting basis value and the carbonate level is 2.5 times the basis value. In order to precipitate the aluminum, the oxalate is added as oxalic acid and the carbonate is added as the bicarbonate species. The difference between the final two formulations is that the Ox-7X includes all of the RCRA hazardous metals while the final formulation (NoRCRA-50X) has none of the hazardous metals. The dissolution test results for both of the final formulations showed very low solubility in the core leachate simulant and some limited solubility in the deionized water consistent with the high levels of oxalate in the simulants. These two formulations meet the needs for an insoluble salt simulant that is based on the Tank $28 \mathrm{~F}$ core analysis. The recipe for producing one liter of the NoRCRA-50X and Ox-7x insoluble salt simulants are listed in Appendix A and B. Additional optimization of the formulation is possible by modifying both the carbonate and oxalate levels around the currently tested values.

\subsection{Insoluble Salt Simulant Composition and Properties}

The preparation of the insoluble salt simulant proceeds from an intermediate product slurry through a thermal concentration step to a final product slurry. The composition and properties information in this section are for the final products. Similar information is available for the intermediate product but the intermediate product has not been tested for dissolution properties. The intermediate product would be expected to contain a greater portion of sludge-like species (aluminum hydroxide, ferric hydroxide, silica, etc.) and less of the lower solubility ionic salts (sodium oxalate, sodium carbonate, sodium fluorophosphate, etc.). 
The solids content of the final RCRA and non-RCRA insoluble salt simulant slurry compositions was measured and is shown in Table 3-4. The weight percent solids were determined using a Mettler Toledo HR73P Halogen Moisture Analyzer. The wt \% total solids for the simulant was measured as was the wt $\%$ dissolved solids in the supernate phase of the simulant. The $\mathrm{wt} \%$ soluble solids and insoluble solids in the slurry were then calculated from these two measured values. ${ }^{4}$ Densities for the two slurry simulants were determined using an Anton Paar DMA 4500 density meter. The density meter determines the density of a sample by measuring the resonant frequency of a sample-filled $U$ tube at a specified temperature.

Table 3-4 Insoluble Salt Simulant Weight Percent Solids, Density and pH Results

\begin{tabular}{|c|c|c|c|}
\hline Units & Ox-7X Simulant & $\begin{array}{c}\text { NoRCRA-50X } \\
\text { Simulant }\end{array}$ \\
\hline Total Solids & $\mathrm{Wt} \%$ & 59.27 & 62.41 \\
\hline Soluble Solids & $\mathrm{Wt} \%$ & 24.93 & 25.19 \\
\hline Insoluble Solids & $\mathrm{Wt} \mathrm{\%}$ & 34.34 & 37.22 \\
\hline Density & $\mathrm{grams} / \mathrm{mL}$ & 1.580 & 1.552 \\
\hline $\mathbf{p H}$ & $\mathrm{pH}$ & $\mathrm{NM}$ & 12.63 \\
\hline
\end{tabular}

NM Not Measured

The high soluble solids content is expected since the simulant has not been washed. Washing the simulant can be counterproductive since it will also remove some of the salts from the solids that are necessary to the simulant. The $\mathrm{pH}$ is consistent with the high carbonate content and the low hydroxide level planned for the simulant.

The primary focus of the insoluble salt simulant is the insoluble portion of the simulant. The insoluble portion of the simulant was recovered by centrifuging the simulant at $3300 \mathrm{rpm}$ for a minimum of 15 minutes using an IEC Centra GP8 centrifuge until the fines are not easily suspended. The supernate phase was carefully decanted and the damp solids were removed for analysis. The solids were then dried at $150{ }^{\circ} \mathrm{C}$. The dried solids were prepared for dissolution by a lithium metaborate/lithium nitrate fusion at $1000{ }^{\circ} \mathrm{C}$ and then dissolved in dilute nitric/hydrochloric acids. The samples were analyzed by ICPES and the results are shown in Table 3-5. Note that "NA" indicates that the element was not added to the simulant. 
WSRC-STI-2008-00079

Revision 0

Table 3-5 ICPES Results for the Insoluble Salt Simulants Centrifuged Dried Solids

\begin{tabular}{|c|c|c|c|}
\hline Element & $\begin{array}{c}\text { Target } \\
\text { wt\% Solids }\end{array}$ & $\begin{array}{c}\text { Ox-7X } \\
\text { wt\% Solids }\end{array}$ & $\begin{array}{c}\text { NoRCRA-50X } \\
\text { wt\% Solids }\end{array}$ \\
\hline $\mathbf{A l}$ & 5.62 & 9.33 & 8.6 \\
\hline $\mathbf{C a}$ & 0.14 & 0.274 & 0.239 \\
\hline $\mathbf{C r}$ & 0.73 & 0.767 & $\mathrm{NA}$ \\
\hline $\mathbf{F e}$ & 0.96 & 1.88 & 1.69 \\
\hline $\mathbf{K}$ & 0.04 & $<0.1$ & $<0.1$ \\
\hline $\mathbf{M o}$ & 0.31 & 0.323 & 0.403 \\
\hline $\mathbf{N a}$ & 15.8 & 23.2 & 24.75 \\
\hline $\mathbf{P}$ & 0.36 & 0.59 & 0.609 \\
\hline $\mathbf{P b}$ & 0.007 & $<0.02$ & $\mathrm{NA}$ \\
\hline $\mathbf{S}$ & 0.54 & 0.562 & 0.712 \\
\hline $\mathbf{S i}$ & 0.71 & 1.36 & 1.245 \\
\hline $\mathbf{W}$ & 0.03 & 0.033 & 0.041 \\
\hline
\end{tabular}

A comparison between the soluble species $(\mathrm{Cr}, \mathrm{Mo}, \mathrm{S}, \mathrm{P}, \mathrm{W})$ and the insoluble species (Al, $\mathrm{Ca}, \mathrm{Fe}, \mathrm{Si}$ ) seems to indicate that the solids are high in the insoluble species as expected but are also higher than the target values. These values are subject to variation depending on the dryness of the solids prepared for analysis. The insoluble salt simulant will be impacted by this issue strongly since many of the salts have varying degrees of hydration which would be impacted by the drying conditions. A better method of evaluating the analytical data for such a material is based on calculating the ratio of each species to the most significant species in the material. For the insoluble salt solids, sodium is the most significant species. Table 3-6 reports the results of the ICPES analysis after calculating the ratio of each element to the value for $\mathrm{Na}$. 
Table 3-6 Simulants Compared to Target Values

\begin{tabular}{|c|c|c|c|c|c|}
\hline Element & $\begin{array}{c}\text { Target } \\
\text { Ratio to Na }\end{array}$ & $\begin{array}{c}\text { Ox-7X } \\
\text { Ratio to Na }\end{array}$ & $\begin{array}{c}\text { Ox-7X } \\
\text { \%o Target }\end{array}$ & $\begin{array}{c}\text { NoRCRA- } \\
\text { 50X } \\
\text { Ratio to Na }\end{array}$ & $\begin{array}{c}\text { NoRCRA- } \\
\text { 50X } \\
\text { \% of Target }\end{array}$ \\
\hline $\mathbf{A l}$ & 0.356 & 0.402 & 112.9 & 0.347 & 97.5 \\
\hline $\mathbf{C a}$ & 0.009 & 0.012 & 133.3 & 0.01 & 111.1 \\
\hline $\mathbf{C r}$ & 0.046 & 0.033 & 71.7 & NA & NA \\
\hline $\mathbf{F e}$ & 0.061 & 0.081 & 132.8 & 0.068 & 111.5 \\
\hline $\mathbf{K}$ & 0.003 & $<0.004$ & $<133$ & $<0.004$ & $<133$ \\
\hline $\mathbf{M o}$ & 0.019 & 0.014 & 73.7 & 0.016 & 84.2 \\
\hline $\mathbf{N a}$ & 1 & 1 & 100.0 & 1 & 100.0 \\
\hline $\mathbf{P}$ & 0.023 & 0.025 & 108.7 & 0.025 & 108.7 \\
\hline $\mathbf{P b}$ & 0.0004 & $<0.0009$ & $<225$ & $\mathrm{NA}$ & $\mathrm{NA}$ \\
\hline $\mathbf{S}$ & 0.034 & 0.024 & 70.6 & 0.029 & 85.3 \\
\hline $\mathbf{S i}$ & 0.045 & 0.059 & 131.1 & 0.05 & 111.1 \\
\hline $\mathbf{W}$ & 0.0018 & 0.0014 & 77.8 & 0.0017 & 94.4 \\
\hline
\end{tabular}

A comparison of the target ratios to those for the two insoluble salt simulants shows that many of the least soluble elements are near or slightly greater than the target values. Since this is based on a ratio to a generally soluble element $(\mathrm{Na})$ then the insoluble solids must include a large amount of $\mathrm{Na}$, just as was observed for the actual insoluble salt solids from the Tank 28F core sample.

The rheology of the insoluble salt simulant product made with no RCRA metals was measured on a Haake RheoStress 600 rheometer (RS600) using a cone and plate sensor (60 mm Ti, 2 degree cone). The flow curve program used on the rheometer is shown in Table 3-7. The measured shear stresses for the down flow curves were fitted to the Bingham Plastic rheology model (equation 1) over the shear rate range of 50 to 600 seconds $^{-1}$.

$$
\tau=\tau_{0}+\eta_{0} \dot{\gamma}
$$

$$
\begin{aligned}
& \tau=\text { shear stress, Pa } \\
& \tau_{0}=\text { Bingham Yield Stress, Pa } \\
& \dot{\gamma}=\text { Shear rate, } 1 / \text { seconds } \\
& \eta_{0}=\text { Bingham Plastic Viscosity (consistency), mPa.sec (or cP) }
\end{aligned}
$$

The Bingham yield stress based on the initial down curve was $26.5 \mathrm{~Pa}$ and the plastic viscosity was 167 $\mathrm{mPa} . \mathrm{sec}$ at $25^{\circ} \mathrm{C}$. The subsequent down curves showed evidence of drying on the perimeter of the cone which would translate to higher stress values. 
Table 3-7 Cone and Plate Rheology Program

\begin{tabular}{|c|c|c|}
\hline $\begin{array}{c}\text { Program } \\
\text { Section }\end{array}$ & $\begin{array}{c}\text { Shear rate, } \\
\text { seconds }\end{array}$ & Time, minutes \\
\hline Initial Hold & 0 & 2 \\
\hline $1^{\text {st }}$ Up Curve & 0 to 600 & 5 \\
\hline $1^{\text {st }}$ Hold & 600 & 2 \\
\hline $1^{\text {st }}$ Down Curve & 600 to 0 & 5 \\
\hline Hold & 0 & 2 \\
\hline $2^{\text {nd }}$ Up Curve & 0 to 600 & 5 \\
\hline $2^{\text {nd }}$ Hold & 600 & 2 \\
\hline $2^{\text {nd }}$ Down Curve & 600 to 0 & 5 \\
Hold & 0 & 2 \\
\hline $3^{\text {rd }}$ Up Curve & 0 to 600 & 5 \\
\hline $3^{\text {rd } H o l d ~}$ & 600 & 2 \\
\hline $3^{\text {rd }}$ Down Curve & 600 to 0 & 5 \\
\hline
\end{tabular}

Tests involving the insoluble salt simulant will probably use an undisturbed or relatively undisturbed bed of solids. Therefore, the settled solids shear strength was measured using the vane method. ${ }^{4}$ An undisturbed sample was measured on the RS600 using the FL-16 vane after 90 hours of settling time. The settled solids shear strength was $81.8 \mathrm{~Pa}$. The time versus shear stress curve for the FL-16 vane is shown in Figure 3-1 and shows the expected shear behavior for a homogenous bed of fluid material.

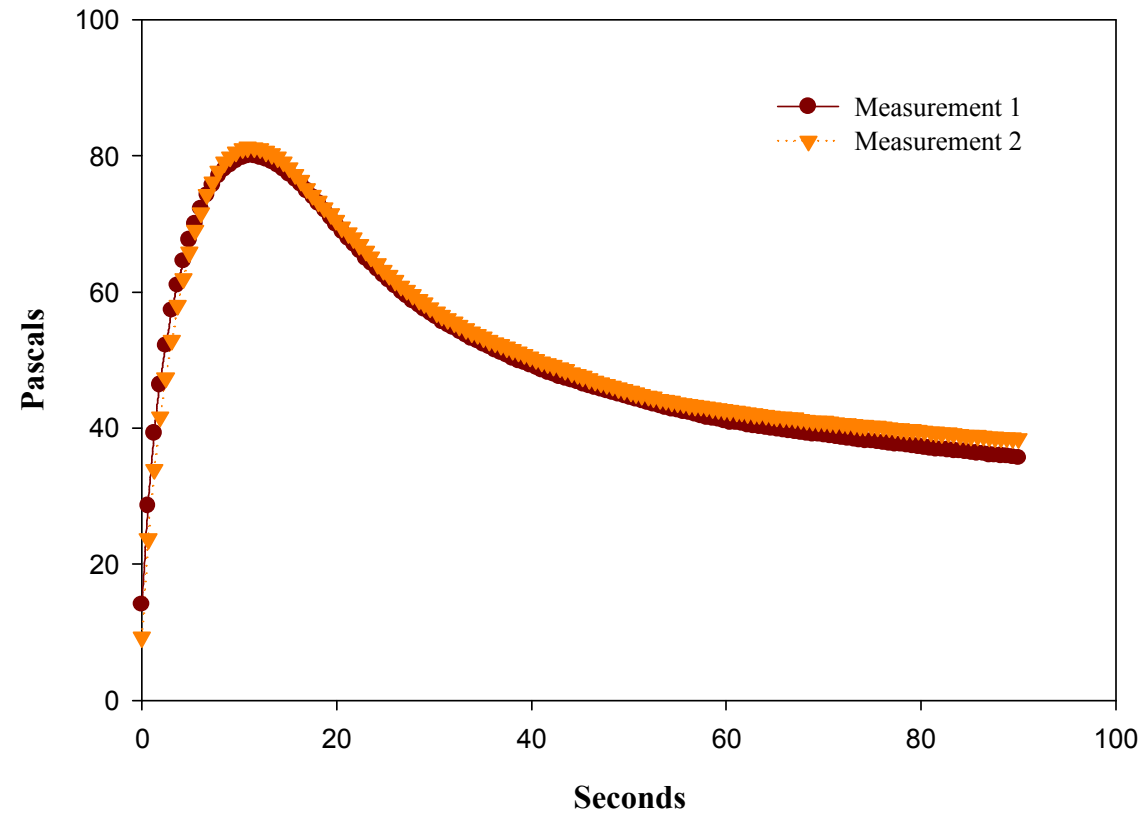

Figure 3-1 Vane Measurement of Settled Solids Shear Strength after 90 Hours Settling 
After 29 days the undisturbed sample of the no RCRA simulant was again prepared for settled solids shear strength analysis. During the preparation, evidence of crystal formation was observed within the settled solids bed as shown in Figure 3-2. These apparently needle-like crystals would probably impact the settled solids shear strength. An attempt to perform a vane measurement resulted in a curve (shown in Figure 3-3) that confirmed that the settled bed was no longer a homogenous fluid.

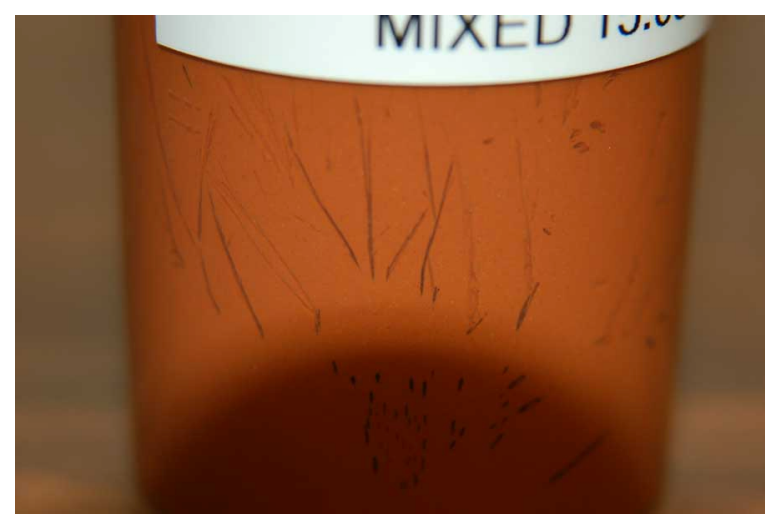

Figure 3-2 Crystals in the NoRCRA Insoluble Salt Simulant

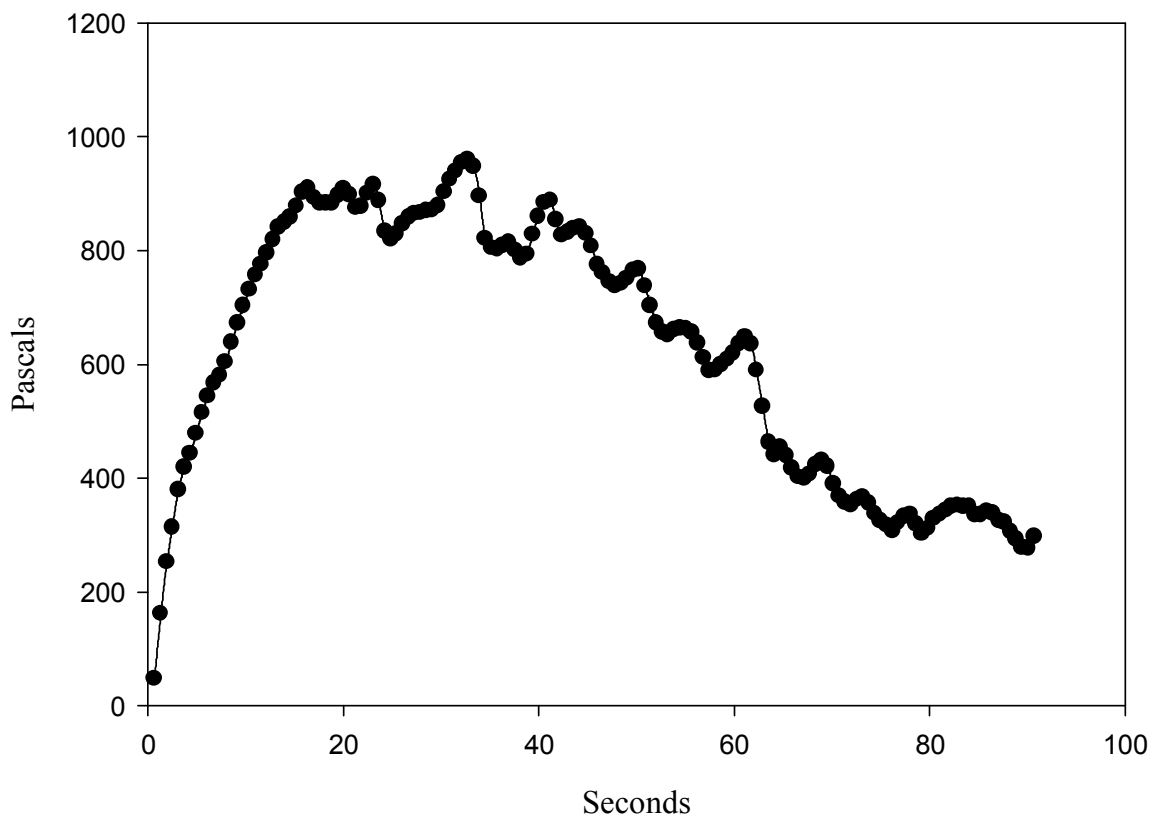

Figure 3-3 Vane Measurement after 29 days

After removing the vane from the sample, a spatula was used to gently mix the bed in an attempt to recover one of the crystals. The crystals were actually clear plates that were easily dissolved in deionized water. Several recovered crystals were allowed to air dry overnight. These dried crystal plates appeared to effloresce and were reduced to a dry powder over several days. This suggested that the crystals might be sodium carbonate decahydrate which is well known for efflorescing as it loses waters of hydration to convert to the monohydrate. Addition of acid to one of the clear crystals generated gas bubbles confirming that the crystal was a carbonate. The crystals that were moved to the surface of the sample are easily seen in Figure 3-4. 


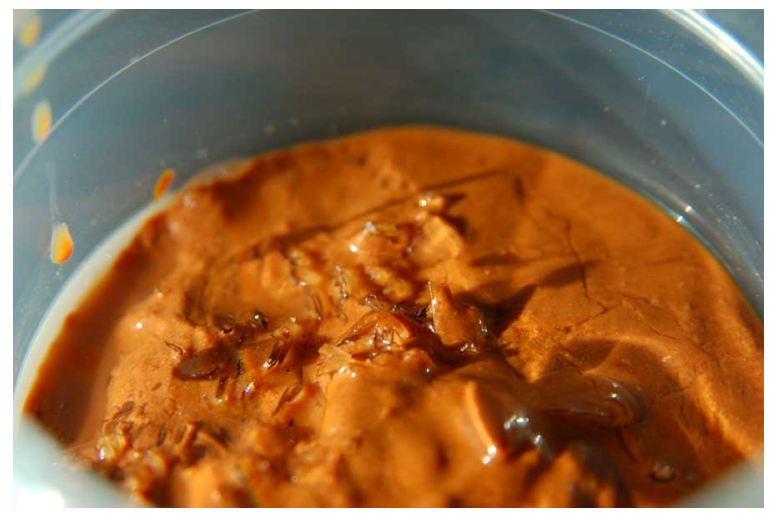

Figure 3-4 Sodium Carbonate Decahydrate Crystals in Insoluble Salt Simulant

The presence of growing crystals in the settled simulant is not unexpected since the supernate associated with the insoluble solids is saturated with respect to the insoluble salts in the simulant. An examination of the simulant that had been mixed every couple days for sampling purposes or for other tests did not show any sign of the large crystals. This suggests that periodic mixing can help prevent growth of crystals. Another possible approach is to not concentrate the mixture quite as much or to modify the simulant to a lower carbonate level. Washing the simulant to dilute the supernate is also a possibility but washing is likely to alter the simulant by dissolution of some of the more soluble salts that are present. Additional testing in this area might be necessary if a large quantity of the simulant is planned to be produced and held for a long period of time before use.

\subsection{ECC Insoluble Salt Simulant Produced for Enhanced Chemical Cleaning Tests}

Testing of potential ECC processes at vendor facilities requires larger than lab-scale quantities of the insoluble salt simulant. Approximately 28 gallons of the final ECC Insoluble Salt Simulant was produced at SRNL in the Engineering Development Lab based on the NoRCRA-50X simulant recipe for use in vendor testing. The simulant was prepared and transferred to an open top 55 gallon drum for ease of mixing and removal at the vendors test facility. The only variation from the recipe detailed in Appendix A was that the simulant was only concentrated to a density of $1.49 \mathrm{~kg} / \mathrm{Liter}$ due to mass limits for open top drums. The physical properties of the 28 gallon batch are shown in Table 3-8. The lower values for the various solids measurements compared to the lab-scale simulant is due to not concentrating to as high a slurry density.

Table 3-8 ECC Insoluble Salt Simulant Physical Properties

\begin{tabular}{|c|c|c|c|}
\hline Units & $\begin{array}{c}\text { ECC Insoluble } \\
\text { Salt Simulant }\end{array}$ & $\begin{array}{c}\text { NoRCRA-50X } \\
\text { Simulant }\end{array}$ \\
\hline Total Solids & $\mathrm{Wt} \%$ & 52.98 & 62.41 \\
\hline Soluble Solids & $\mathrm{Wt} \%$ & 21.93 & 25.19 \\
\hline Insoluble Solids & $\mathrm{Wt} \%$ & 31.06 & 37.22 \\
\hline Density & $\mathrm{grams} / \mathrm{mL}$ & 1.489 & 1.552 \\
\hline $\mathbf{p H}$ & $\mathrm{pH}$ & 12.80 & 12.63 \\
\hline
\end{tabular}


Dissolution testing on the large batch ECC Insoluble Salt simulant was conducted as described in Section 3.1. The dissolution test results are compared to the NoRCRA-50X simulant in Table 3-9. The centrifuged solids for the large batch of simulant also showed very little dissolution when contacted with a solution already containing greater than 2 moles/liter of sodium ion.

Table 3-9 Dissolution Test Results for the ECC Insoluble Salt Simulant

\begin{tabular}{|c|c|c|}
\hline $\begin{array}{c}\text { Dissolution } \\
\text { Tests }\end{array}$ & $\begin{array}{c}\text { NoRCRA- } \\
\mathbf{5 0 X} \\
\text { \% } \\
\text { Dissolved }\end{array}$ & $\begin{array}{c}\text { Final ECC } \\
\text { Insoluble } \\
\text { Simulant } \\
\text { \% Dissolved }\end{array}$ \\
\hline $\begin{array}{c}\text { Deionized } \\
\text { Water } \\
\text { Tank 28 Core } \\
\text { Leachate }\end{array}$ & $22.1 \pm 4.2$ & $21.3 \pm 0.1$ \\
\hline
\end{tabular}

Chemical analysis of the ECC Insoluble Salt Simulant was conducted using ICPES and ion chromatography. A portion of the simulant was dried at $150{ }^{\circ} \mathrm{C}$ and then a weighed portion was dissolved as previously described in Section 3.2 and the total solids analyzed by ICPES. The results of the analysis are listed in Table 3-10.

Table 3-10 Elemental Analysis Results for the ECC Insoluble Salt Simulant

\begin{tabular}{|c|c|c|c|c|}
\hline Element & $\begin{array}{c}\text { ICP Result, } \\
\text { wt \% Solids }\end{array}$ & $\begin{array}{c}\text { ICP Result, } \\
\text { Moles/Mole } \\
\text { Na }\end{array}$ & $\begin{array}{c}\text { Target, } \\
\text { Moles/Mole Na }\end{array}$ & $\begin{array}{c}\text { \% of } \\
\text { Target }\end{array}$ \\
\hline $\mathbf{A l}$ & 8.34 & 0.303 & 0.303 & 100 \\
\hline $\mathbf{C a}$ & 0.22 & 0.0055 & 0.005 & 105 \\
\hline $\mathbf{F e}$ & 1.62 & 0.028 & 0.025 & 114 \\
\hline $\mathbf{K}$ & 0.09 & 0.0022 & 0.0015 & 145 \\
\hline $\mathbf{M o}$ & 0.43 & 0.0044 & 0.0047 & 93 \\
\hline $\mathbf{N a}$ & 23.45 & 1.00 & 1.00 & 100 \\
\hline $\mathbf{P}$ & 0.52 & 0.016 & 0.017 & 98 \\
\hline $\mathbf{S}$ & 0.62 & 0.019 & 0.024 & 78 \\
\hline $\mathbf{S i}$ & 1.38 & 0.048 & 0.037 & 130 \\
\hline $\mathbf{W}$ & 0.04 & 0.000227 & 0.00023 & 99 \\
\hline
\end{tabular}

The only species that are higher than the targeted amount are those expected to be either a contaminant in the large quantity of reagents added $(\mathrm{K})$ or were added as a hydrate which may have been a little low in water content $(\mathrm{Si})$. Most of the species are very close to their target values as compared to the Na content.

The supernate from the ECC Insoluble Salt Simulant was separated by centrifuging as previously described for 30 minutes. The supernate density was 1.291 grams $/ \mathrm{mL}$ and the supernate $\mathrm{pH}$ was 12.66 . The supernate was analyzed by ICPES and IC and the results are shown in Table 3-11. 
Table 3-11 ECC Insoluble Salt Simulant Supernate Composition

\begin{tabular}{|c|c|c|c|}
\hline Species & Method & $\begin{array}{c}\text { Concentration } \\
\text { mg/Liter }\end{array}$ & $\begin{array}{c}\text { Concentration } \\
\text { Moles/Liter }\end{array}$ \\
\hline $\mathbf{A l}$ & ICPES & 2745 & 0.102 \\
\hline $\mathbf{C a}$ & ICPES & 1.5 & 0.000037 \\
\hline $\mathbf{F}$ & IC & 106 & 0.0056 \\
\hline $\mathbf{F e}$ & ICPES & $<1.0$ & $<0.00002$ \\
\hline $\mathbf{K}$ & ICPES & 1225 & 0.031 \\
\hline $\mathbf{M o}$ & ICPES & 4915 & 0.051 \\
\hline $\mathbf{N a}^{-}$ & ICPES & 137000 & 5.96 \\
\hline $\mathbf{N O}_{\mathbf{3}}^{-}$ & IC & 153000 & 2.47 \\
\hline $\mathbf{O x a l a t e}_{\mathbf{n}}$ & IC & $<100$ & $<0.0011$ \\
\hline $\mathbf{P}$ & ICPES & 2710 & 0.087 \\
\hline $\mathbf{S}$ & ICPES & 8385 & 0.26 \\
\hline $\mathbf{S i}$ & ICPES & 20 & 0.0007 \\
\hline $\mathbf{W}$ & ICPES & 377 & 0.0021 \\
\hline
\end{tabular}

By combining the information in Table 3-11 with the $\mathrm{pH}$ and applying charge balance requirements, the concentration of carbonate anion in the supernate is calculated to be $1.24 \mathrm{moles} / \mathrm{Liter}$. Using this information with measured composition of the total solids and applying mass balance and charge balance considerations, the composition of the insoluble solids in the ECC Insoluble Salt Simulant was calculated based on possible simple assumed compounds and is shown in Table 3-12.

Table 3-12 Calculated Composition of the ECC Insoluble Salt Simulant Solids

\begin{tabular}{|c|c|c|}
\hline Compound & Formula & $\begin{array}{c}\text { Wt \%o } \\
\text { Basis }\end{array}$ \\
\hline Aluminum Hydroxide & $\mathrm{Al}(\mathrm{OH})_{3}$ & 37.0 \\
\hline Calcium Carbonate & $\mathrm{CaCO}_{3}$ & 0.9 \\
\hline Ferric Hydroxide & $\mathrm{Fe}(\mathrm{OH})_{3}$ & 4.9 \\
\hline $\begin{array}{c}\text { Sodium Fluoride } \\
\text { Phosphate }\end{array}$ & $\mathrm{Na}_{3} \mathrm{~F}\left(\mathrm{PO}_{4}\right)_{2} .19 \mathrm{H}_{2} \mathrm{O}$ & 3.6 \\
\hline Silica & $\mathrm{SiO}_{2}$ & 4.7 \\
\hline Sodium Nitrate & $\mathrm{NaNO}_{3}$ & 2.4 \\
\hline Sodium Oxalate & $\mathrm{Na}_{2} \mathrm{C}_{2} \mathrm{O}_{4}$ & 46.5 \\
\hline
\end{tabular}

The data definitely indicated that almost all of the added oxalate was insoluble and that most of the added carbonate was still soluble when the simulant is only concentrated to less than $1.5 \mathrm{~g} / \mathrm{mL}$ density. The presence of insoluble fluoride and phosphate was also indicated which could be represented by the known double salt shown in the table whose presence has been observed in other salt waste tanks at Hanford. ${ }^{5}$ Direct measurement of these compounds by another method such as polarized light microscopy or x-ray crystallography was not attempted due to the difficulty of removing the supernate without dissolving the more soluble species. Salts such as the sodium oxalate or the fluoride phosphate double salt are soluble if sufficient water is added to maintain a low $\mathrm{Na}$ ion concentration. During Salt dissolution with minimized 
WSRC-STI-2008-00079

Revision 0

water additions, the $\mathrm{Na}$ concentration will be high (as the nitrate and nitrite salts are dissolved) and the low solubility salts present in the simulant will not dissolve. 


\subsection{CONCLUSIONS}

An insoluble salt simulant has been developed based upon the residues from salt dissolution of saltcake core samples from Tank 28F. The simulant was developed for use in testing SRS waste tank chemical cleaning methods. Based on the results of the simulant development process, the following observations were developed:

- A composition based on 10.35 grams oxalate and 4.68 grams carbonate per 100 grams solids produces a sufficiently insoluble solids simulant.

- Aluminum observed in the solids remaining from actual waste salt dissolution tests is probably precipitated from sodium aluminate due to the low hydroxide content of the saltcake.

- In-situ generation of aluminum hydroxide (by use of aluminate as the Al source) appears to trap additional salts in the simulant in a manner similar to that expected for actual waste samples.

- Alternative compositions are possible with higher oxalate levels and lower carbonate levels. The maximum oxalate level is limited by the required Na content of the insoluble solids.

- Periodic mixing may help to limit crystal growth in this type of salt simulant.

- Long term storage of an insoluble salt simulant is likely to produce a material that can not be easily removed from the storage container. Production of a relatively fresh simulant is best if pumping the simulant is necessary for testing purposes.

The insoluble salt simulant was developed to duplicate the probable composition and expected chemistry of the insoluble salts remaining after actual salt dissolution. The simulant does not necessarily reflect the actual salt solids physical properties such as crystallinity, permeability, and particle size and density. Testing that involves these physical properties should be focused on actual waste samples instead of simulants. 
WSRC-STI-2008-00079

Revision 0

This page intentionally left blank. 


\subsection{RECOMMENDATIONS/PATH FORWARD}

The insoluble salt simulant described in this report represents the initial attempt to represent the material which may be encountered during final waste removal and tank cleaning. Additional improvements to the insoluble salt simulant are possible. During the development of these simulants it was recognized that:

- Additional waste characterization on the residues from salt dissolution tests with actual tank waste samples to determine the amount of species such as carbonate, oxalate and aluminosilicate would allow fewer assumptions to be made in constructing an insoluble salt simulant.

- The tank history will impact the amount and type of insoluble solids that exist in the salt dissolution solids. Varying the method of simulant production (elevated temperature processing time, degree of evaporation, amount of mixing (shear) during preparation, etc.) should be tested. 
WSRC-STI-2008-00079

Revision 0

This page intentionally left blank. 


\subsection{REFERENCES}

1. Martino, C. J., McCabe, D. J., Edwards, T. B. and R. L. Nichols. Analysis of Tank 28F Saltcake Core Samples FTF-456 - 467. WSRC-STI-2006-00151, Rev 0. Savannah River Site, Aiken SC 29808 (February 28, 2007).

2. Martino, C. J., Nichols, R. L., McCabe, D. J., Millings, M. R. and M. E. Denham. Tanks 3F and 2F Saltcake Core and Supernate Sample Analysis. WSRC-TR-2004-00131, Rev 0. Savannah River Site, Aiken SC 29808 (April 13, 2004).

3. D. L. Herting. Results of Dilution Studies with Waste from Tank 241-AN-105. HNF-SDWM-DTR-046, Rev. 0, Numatec Hanford Corporation, Richland, WA 99352 (October 10, 1997).

4. Eibling, R. E., Hansen, E. K. and B. R. Pickenheim. Potential Impact of Blending Residual Solids from Tank 18/19 Mounds with Tank 7 Operations. WSRC-STI-2007-00113, Rev 0. Savannah River Site, Aiken SC 29808 (March 2007).

5. Herting, D. L. and G. A. Cooke. Identification of Solid Phases in Saltcake from Hanford Site Waste Tanks. HNF-11585, Rev 0. Fluor Hanford, Richland WA (September 25, 2002). 
WSRC-STI-2008-00079

Revision 0

This page intentionally left blank. 
WSRC-STI-2008-00079

Revision 0

\subsection{ACKNOWLEDGEMENTS}

This project could not have been completed without the assistance of Michael Williams, David Best, Frances Williams, and Jon Duval. 
WSRC-STI-2008-00079

Revision 0

This page intentionally left blank. 
WSRC-STI-2008-00079

Revision 0

APPENDIX A. Insoluble Salt Simulant Recipe without RCRA Metals 
The following simulant recipe is for preparing one liter of insoluble salt simulant containing no RCRA metals. Note that the values below can be scaled to a desired batch size in liters.

Recipe for preparing an insoluble salt simulant which contains no RCRA metals

Final Insoluble Salt Simulant Batch Size

Initial Slurry Target

Density

Initial Batch Volume to be Prepared

\begin{tabular}{|l|c|}
\cline { 2 - 2 } \multicolumn{1}{l|}{ Add to the tank } & grams \\
\hline Water & 333.4 \\
\hline
\end{tabular}

Add to the tank

\begin{tabular}{|c|c|c|}
\hline Compounds & Formula & $\begin{array}{c}\text { Mass } \\
\text { Needed, } \\
\text { grams }\end{array}$ \\
\hline Ferric Nitrate & $\mathrm{Fe}\left(\mathrm{NO}_{3}\right)_{3} \cdot 9 \mathrm{H}_{2} \mathrm{O}$ & 101.17 \\
\hline Calcium Nitrate & $\mathrm{Ca}\left(\mathrm{NO}_{3}\right)_{2} \cdot 4 \mathrm{H}_{2} \mathrm{O}$ & 12.35 \\
\hline
\end{tabular}

All the compounds should completely dissolve.

Add to the tank

\begin{tabular}{|c|c|c|}
\hline Compounds & Formula & $\begin{array}{c}\text { Mass } \\
\text { Needed, } \\
\text { grams }\end{array}$ \\
\hline Sodium Hydroxide & $\mathrm{NaOH}, 50 \mathrm{wt} \%$ & 182.11 \\
\hline $\begin{array}{c}\text { Sodium Aluminum } \\
\text { Oxide }\end{array}$ & $\mathrm{NaAlO}_{2}$ & 248.48 \\
\hline
\end{tabular}

Mix thoroughly. Will produce solids which will remain suspended while being agitated.

Cooling may be required to keep the solution below $60^{\circ} \mathrm{C}$ (recommended )

Maintain agitation while adding the following 


\begin{tabular}{|c|c|c|}
\hline Compounds & Formula & $\begin{array}{c}\text { Mass } \\
\text { Needed, } \\
\text { grams }\end{array}$ \\
\hline Potassium Nitrate & $\mathrm{KNO}_{3}$ & 1.51 \\
\hline $\begin{array}{c}\text { Sodium Molybdate, } \\
\text { Dihydrate }\end{array}$ & $\mathrm{Na}_{2} \mathrm{MoO}_{4} \cdot 2 \mathrm{H}_{2} \mathrm{O}$ & 11.30 \\
\hline $\begin{array}{c}\text { Sodium Metasilicate, } \\
\text { Pentahydrate }\end{array}$ & $\mathrm{Na}_{2} \mathrm{SiO}_{3} \cdot 5 \mathrm{H}_{2} \mathrm{O}$ & 78.49 \\
\hline $\begin{array}{c}\text { Sodium Tungstate, } \\
\text { Dihydrate }\end{array}$ & $\mathrm{Na}_{2} \mathrm{WO}_{4} \cdot 2 \mathrm{H}_{2} \mathrm{O}$ & 0.76 \\
\hline Sodium Fluoride & $\mathrm{NaF}_{2}$ & 2.19 \\
\hline Oxalic Acid & $\mathrm{H}_{2} \mathrm{C}_{2} \mathrm{O}_{4} \cdot 2 \mathrm{H}_{2} \mathrm{O}$ & 237.32 \\
\hline Sodium Sulfate & $\mathrm{Na}_{2} \mathrm{SO}_{4}$ & 34.50 \\
\hline Sodium Phosphate & $\mathrm{Na}_{3} \mathrm{PO}_{4} \cdot 12 \mathrm{H}_{2} \mathrm{O}$ & 63.58 \\
\hline Sodium Bicarbonate & $\mathrm{NaHCO}_{3}$ & 99.64 \\
\hline
\end{tabular}

Mix completely then

add

\begin{tabular}{|c|c|c|}
\hline Compounds & Formula & $\begin{array}{c}\text { Mass } \\
\text { Needed, } \\
\text { grams }\end{array}$ \\
\hline Water & $\mathrm{H}_{2} \mathrm{O}$ & 722.45 \\
\hline Sodium Nitrate & $\mathrm{NaNO}_{3}$ & 132.88 \\
\hline
\end{tabular}

Mix Completely and then maintain mixing overnight.
Measure the slurry density.
The slurry density should be
$\mathbf{g} / \mathbf{m L}$

Heat the slurry to a temperature greater than $90^{\circ} \mathrm{C}$ while maintaining agitation. Then concentrate by removing the amount of condensate shown below.

(Note that boiling to remove the condensate is acceptable ) Agitation must be maintained while heating the slurry.

\begin{tabular}{|l|l|l|}
\cline { 3 - 3 } \multicolumn{2}{l|}{} & $\begin{array}{l}\text { Mass to } \\
\text { Remove, } \\
\text { grams }\end{array}$ \\
\hline Condensate to Remove & $\mathrm{H}_{2} \mathrm{O}$ & 666.8 \\
\hline
\end{tabular}

Remix and measure the density (expected density is $1.55 \mathrm{~g} / \mathrm{mL}$ ) 
WSRC-STI-2008-00079

Revision 0

This page intentionally left blank. 
WSRC-STI-2008-00079

Revision 0

\section{APPENDIX B. Insoluble Salt Simulant Recipe with RCRA Metals}


The following simulant recipe is for preparing one liter of insoluble salt simulant containing RCRA metals. Note that the values below can be scaled to a desired batch size in liters.

Insoluble Salt Supernate with RCRA metals

Final Insoluble Salt Simulant Batch Size

Initial Slurry Target Density

Initial Volume to be Batched

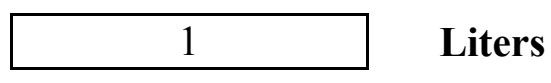

$1.367 \quad \mathbf{g} / \mathbf{m L}$

$1667 \quad \mathbf{m L}$

\begin{tabular}{|l|c|}
\cline { 2 - 2 } \multicolumn{1}{l|}{ Add to vessel } & grams \\
\hline Water & 333.4 \\
\hline
\end{tabular}

Add to the Vessel:

\begin{tabular}{|l|l|c|}
\hline Compounds & Formula & $\begin{array}{c}\text { Mass Needed, } \\
\text { grams }\end{array}$ \\
\hline Ferric Nitrate & $\mathrm{Fe}\left(\mathrm{NO}_{3}\right)_{3} \cdot 9 \mathrm{H}_{2} \mathrm{O}$ & 101.17 \\
\hline Lead Nitrate & $\mathrm{Pb}\left(\mathrm{NO}_{3}\right)_{2}$ & 0.15 \\
\hline Calcium Nitrate & $\mathrm{Ca}\left(\mathrm{NO}_{3}\right)_{2} \cdot 4 \mathrm{H}_{2} \mathrm{O}$ & 12.35 \\
\hline
\end{tabular}

All the compounds should completely dissolve.

Add to the Vessel

\begin{tabular}{|l|l|c|}
\hline Compounds & Formula & $\begin{array}{c}\text { Mass Needed, } \\
\text { grams }\end{array}$ \\
\hline Sodium Aluminum Oxide & $\mathrm{NaAlO}_{2}$ & 248.48 \\
\hline Sodium Hydroxide & $\mathrm{NaOH}, 50 \mathrm{wt} \%$ & 194.78 \\
\hline
\end{tabular}

Mix thoroughly. Will produce solids which will remain suspended while being agitated.

Next add the following

\begin{tabular}{|l|l|c|}
\hline Compounds & Formula & $\begin{array}{c}\text { Mass Needed, } \\
\text { grams }\end{array}$ \\
\hline Sodium Chromate & $\mathrm{Na}_{2} \mathrm{CrO}_{4}$ & 33.28 \\
\hline Potassium Nitrate & $\mathrm{KNO}_{3}$ & 1.51 \\
\hline Sodium Molybdate, Dihydrate & $\mathrm{Na}_{2} \mathrm{MoO}_{4} \cdot 2 \mathrm{H}_{2} \mathrm{O}$ & 11.30 \\
\hline Sodium Metasilicate, Nonahydrate & $\mathrm{Na}_{2} \mathrm{SiO}_{3} \cdot 9 \mathrm{H}_{2} \mathrm{O}$ & 105.15 \\
\hline Sodium Tungstate, Dihydrate & $\mathrm{Na}_{2} \mathrm{WO}_{4} \cdot 2 \mathrm{H}_{2} \mathrm{O}$ & 0.76 \\
\hline
\end{tabular}




\begin{tabular}{|l|l|c|}
\hline Sodium Fluoride & $\mathrm{NaF}$ & 2.19 \\
\hline Oxalic Acid & $\mathrm{H}_{2} \mathrm{C}_{2} \mathrm{O}_{4} \cdot 2 \mathrm{H}_{2} \mathrm{O}$ & 215.74 \\
\hline Sodium Sulfate & $\mathrm{Na}_{2} \mathrm{SO}_{4}$ & 34.50 \\
\hline Sodium Phosphate & $\mathrm{Na}_{3} \mathrm{PO}_{4} \cdot 12 \mathrm{H}_{2} \mathrm{O}$ & 63.58 \\
\hline Sodium Bicarbonate & $\mathrm{NaHCO}_{3}$ & 99.64 \\
\hline
\end{tabular}

Mix completely then add

\begin{tabular}{|l|l|c|}
\hline Compounds & Formula & $\begin{array}{c}\text { Mass Needed, } \\
\text { grams }\end{array}$ \\
\hline Water & $\mathrm{H}_{2} \mathrm{O}$ & 722.99 \\
\hline Sodium Nitrate & $\mathrm{NaNO}_{3}$ & 97.83 \\
\hline
\end{tabular}

Mix Completely and then maintain mixing overnight.

\begin{tabular}{|c|c|}
\hline Measure the slurry density. & $\begin{array}{c}\text { The slurry } \\
\text { density should }\end{array}$ \\
\hline
\end{tabular}

Heat the slurry to a temperature greater than $90 \mathrm{C}$ while maintaining agitation. Then concentrate by removing the amount of condensate shown below.

(Note that boiling to remove the condensate is acceptable ) Agitation must be maintained while heating the slurry.

\begin{tabular}{|l|l|c|}
\cline { 3 - 3 } \multicolumn{2}{c|}{} & $\begin{array}{c}\text { Mass to Remove, } \\
\text { grams }\end{array}$ \\
\hline Condensate to Remove & $\mathrm{H}_{2} \mathrm{O}$ & 666.8 \\
\hline
\end{tabular}

Remix and measure the density (expected density is $1.58 \mathrm{~g} / \mathrm{mL}$ ) 


\section{Distribution:}

J. C. Griffin, 773-A

D. A. Crowley, 999-W

C. C. Herman, 773-42A

B. J. Giddings, 786-5A

W. R. Wilmarth, 773-42A

N. E. Bibler, 773-A

C.M. Jantzen, 773-A

J. R. Harbour, 773-42A

C. A. Langton, 773-43A

D. J. McCabe, 773-42A

W. D. King, 773-42A

M. R. Williams, 786-5A

D. R. Best, 786-1A

M. J. Mahoney, 766-H

R. H. Spires, 766-H

T. N. Crouse, 766-H

E. T. Ketusky, 766-H

T. M. Punch, 766-H 